\title{
Meta-Analysis: Effect of Probiotics on the Frequency and Duration of Diarrhea in Children Under Five
}

\author{
Wahyu Agustin Dwi Ciptaningtyas'), Bhisma Murti²), Setyo Sri Rahardjo3) \\ 1) Masters Program in Public Health, Universitas Sebelas Maret \\ 2) Department of Public Health, Faculty of Medicine, Universitas Sebelas Maret
}

\section{ABSTRACT}

Background: Digestive tract disease is still a health problem around the world, currently there are 2,544,084 cases of diarrhea in Indonesia in 2016. In the Central Java region, there are an estimated of 911,901 cases of diarrhea, while 95,635 cases of diarrhea have been handled. This study aims to estimate the magnitude of the effect of probiotics on the frequency and duration of diarrhea among toddler based on the results of a number of similar previous studies.

Subjects and Method: This study was a systematic study and meta-analysis, with PICO as follows: Population $=$ children under five. Intervention $=$ Probiotics. Comparison $=$ Not Probiotic. Outcome $=$ Frequency and Duration of Diarrhea in toddlers. The articles used in this study were obtained from several databases including PubMed, Springer Link, Cochrane Database, Hindawi, Elsevier, JBBA, LWW, Google Scholar. The keywords for searching articles are as follows: "Probiotic", OR "frequency", OR "diarrhea", "kid", OR child "AND" Randomized Controlled Trial (RCT). The articles included in this study were full text articles with a randomized controlled trial study design. Articles were collected using PRISMA flow diagrams. Articles were analyzed using the Review Manager 5.3 application.

Results: A total of 12 articles reviewed in this meta-analysis study originated from India, Canada, Indonesia, America, Iran. Studies showed that the effect of probiotics decreased the frequency (Standarized mean difference $0.32 ; 95 \% \mathrm{CI}=-0.67$ to $0.03 \mathrm{p}=0.070$ ). The effect of probiotics reduced the duration of diarrhea in children under five (Standarized mean difference $=-0.74 ; 95 \% \mathrm{CI}=-1.60$ to 0.12 $\mathrm{p}=0.090$ ).

Conclusion: Probiotics reduced the frequency and duration of diarrhea in toddlers.

Keywords: Probiotics, Frequency, Diarrhea, Toddlers

\section{Correspondence:}

Wahyu Agustin Dwi Ciptaningtyas. Masters Program in Public Health, Universitas Sebelas Maret. Jl. Ir. Sutami 36A, Surakarta 57126, Central Java. Email: agustinfaa@gmail.com.

\section{Cite this as:}

Ciptaningtyas WAD, Bhisma Murti B, Rahardjo SS (Year). Meta-Analysis: Effect of Probiotics on the Frequency and Duration of Diarrhea in Children Under Five. Indones J Med. 05(04): 321-330. https://doi.org/10.26911/theijmed.2020.05.04.07.

c) Indonesian Journal of Medicine is licensed under a Creative Commons

EY NC SA Attribution-NonCommercial-ShareAlike 4.o International License.

\section{BACKGROUND}

Diarrheal disease is one of the health problems with a high degree of morbidity and mortality in various countries, especially in developing countries such as Indonesia, where morbidity and mortality are still high, and is one of the main causes of high morbidity and mortality rates for children in Indonesia (Vrese and Marteau, 2020).
Acute diarrhea is still a major cause of child morbidity and mortality in developing countries. In the world there are nearly 1.7 billion cases of diarrhea in children every year (WHO, 2017).

There are 6 million children die each year because of diarrhea and most of these occurrences occur in developing countries. In Indonesia, it is estimated that about 60 
million people with diarrhea are found each year, most (70-80\%) of these sufferers are children under 5 years of age $( \pm 40$ million cases(Rajagukguk, 2013).

Probiotics are a mucosal defense, a protective function and defense of gastrointestinal immunity such as the epithelial layer, mucus layer, peristalsis, and epithelial desquamation, as well as the secretion of immunoglobulin A (IgA), which greatly affect the attachment of pathogenic bacteria and also for modulation of the local and systemic immune system (Htwe, 2008).

Probiotics in children aged 36 months old did not decrease the duration of diarrhea with less frequency of defecation, but the difference was not significant (Waspada, 2012) with 1 month -5 years old compared to those without probiotics. (Hatta et al., 2011).

Giving probiotics to children aged 6 36 months did not decrease the duration of diarrhea with less frequency of defecation, but the difference was not significant (Waspada, 2012).

Based on the high number of diarrhea patients in children and the need for patient care based on strong evidence about the use of appropriate probiotics, it is necessary to conduct study to determine whether the addition of probiotics to standard diarrhea therapy will have a better effect on reducing the frequency and duration of diarrhea in children (Hatta et al., 2011).

Probiotics are non-digestible fibers that can stimulate the growth of microorganisms in the colon such as Lactobacillus and bifidobacteria. Some examples of prebiotics are oligosaccharides, maltodextrin, inulin and others (Pandey et al., 2013).

Currently, more and more people claim the beneficial effects of probiotics, including improving intestinal health, increasing immune response, lowering serum cholesterol, and preventing cancer. This advantage is specific to the bacterial strain (SKRT, 2011).

Probiotics are non-digestible fibers that can stimulate the growth of microorganisms in the colon such as Lactobacillus and bifidobacteria. Some examples of prebiotics are oligosaccharides, maltodextrin, inulin and others (Pandey et al., 2013).

Giving probiotics and zinc to children aged 1 month - 12 years old had a significant effect on feces consistency, frequency of diarrhea, duration of diarrhea, and length of stay (Lolopayung et al., 2014).

Giving probiotics to children aged 6 36 months did not decrease the duration of diarrhea with less frequency of defecation, but this difference was not significant (Waspada, 2012).

Appropriate use of probiotics to standard diarrhea therapy will have a better effect on reducing the frequency and duration of diarrhea in pediatric patients (Hatta et al., 2011).

\section{SUBJECTS AND METHOD}

\section{Study Design}

This study was a systematic and meta-analysis study. The articles used in this study were obtained from several databases including PubMed, Springer Link, Cochrane Database, Hindawi, Elsevier, JBBA, LWW, Google Scholar. The keywords for finding articles are as follows: "Probiotic", OR "frequency", OR "diarrhea”, "kid”, OR child "AND "Randomized Controlled Trial (RCT).

\section{Inclusion Criteria}

The article included in this study is a full paper article with a randomized controlled trial study design. The subject of the study was diarrhea sufferers in toddlers. Selected articles discussed the effects of probiotics on the frequency and duration of diarrhea 
in toddlers. The intervention given in the article is in the form of probiotics.

\section{Exclusion Criteria}

Articles published in this study are articles with research designs with non-RCT studies, articles are not full text, articles published before 2010 and the articles are not published in English.

\section{Operational Definition}

The article search was carried out by considering the eligibility criteria defined using the PICO model. The population in the study of diarrhea sufferers among children under five, intervention was a probiotic comparison, which was no probiotic and the outcome was reducing the frequency and duration of diarrhea in toddlers.

Microbial probiotics that stimulate the growth of other microbes, live microorganisms which, when administered in adequate quantities.
Frequency is a measure of the frequency of discharge per day with abnormal consistency with a categorical scale.

Diarrhea is how often the feces is passed over a certain period of time with an abnormal consistency.

\section{Data Analysis}

Data processing was carried out by the Review Manager (RevMan 5.3) by calculating the mean difference to determine the research model that was combined and formed the final meta-analysis result.

\section{RESULTS}

The process of searching for articles done by searching through a database with journals can be seen in Figure 1. Articles obtained from 2 continents, namely America and Asia.

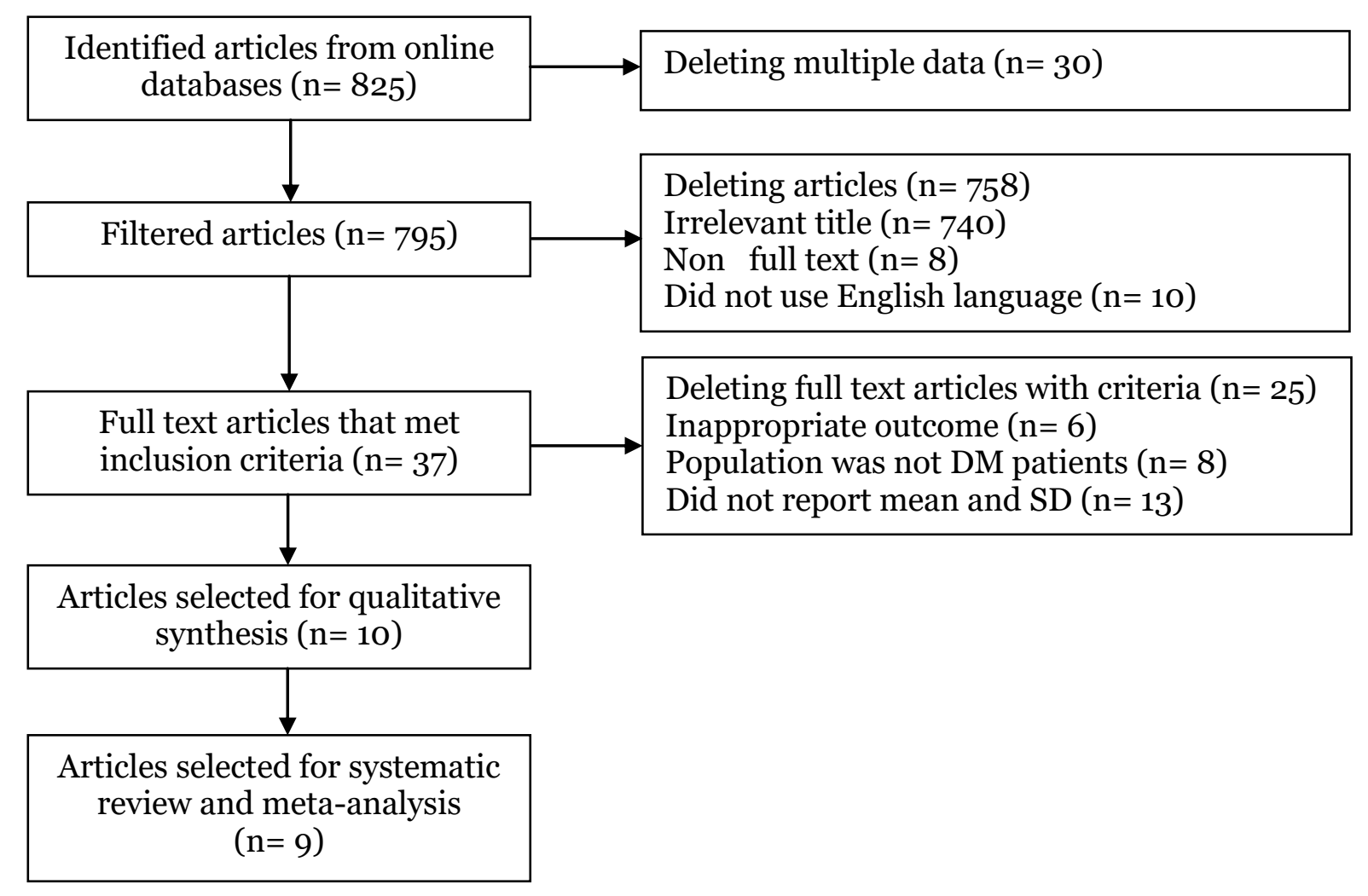

Figure 1. PRISMA flow diagram 
Ciptaningtyas et al./ Effect of Probiotics on the Frequency and Duration of Diarrhea

Figure 2. Assessment of the quality of studies: effect of probiotic on the frequency of diarrhe

\begin{tabular}{|c|c|c|c|c|c|c|c|}
\hline Publication & Cohort & $\begin{array}{l}\text { With } \\
\text { control } \\
\text { group }\end{array}$ & $\begin{array}{l}\text { Pre/post } \\
\text { Interven } \\
\quad \text { etion }\end{array}$ & $\begin{array}{c}\text { Random } \\
\text { assignment }\end{array}$ & $\begin{array}{c}\text { Random } \\
\text { selection of } \\
\text { assignment }\end{array}$ & $\begin{array}{c}\text { Sample } \\
\text { size } \\
(>100)\end{array}$ & $\begin{array}{c}\text { Follow } \\
\text { up rate } \\
>80 \%\end{array}$ \\
\hline $\begin{array}{l}\text { Bnat et al. } \\
(2018)\end{array}$ & 1 & 1 & 1 & 1 & 1 & 1 & 1 \\
\hline $\begin{array}{l}\text { Mirsa et al. } \\
\text { (2009) }\end{array}$ & 1 & 1 & 1 & 1 & 1 & 1 & 1 \\
\hline $\begin{array}{l}\text { Rajaguguk et } \\
\text { al. (2013) }\end{array}$ & 1 & 1 & 1 & 1 & 1 & 1 & 1 \\
\hline $\begin{array}{l}\text { Sharif et al. } \\
(2016)\end{array}$ & 1 & 1 & 1 & 1 & 1 & 1 & 1 \\
\hline $\begin{array}{l}\text { Sharif et al. } \\
\text { (2017) }\end{array}$ & o & 1 & o & 1 & 1 & 1 & 1 \\
\hline $\begin{array}{l}\text { Sudha et al. } \\
\text { (2019) }\end{array}$ & 1 & 1 & $\mathrm{O}$ & 1 & 1 & 1 & 1 \\
\hline
\end{tabular}

Figure 4. Assessment of the quality of studies on duration in toddlers

\begin{tabular}{lcccccccc}
\hline Publication & Cohort & $\begin{array}{c}\text { With } \\
\text { control } \\
\text { group }\end{array}$ & $\begin{array}{c}\text { Pre/post } \\
\text { Interven- } \\
\text { tion }\end{array}$ & $\begin{array}{c}\text { Random } \\
\text { assignment }\end{array}$ & $\begin{array}{c}\text { Random } \\
\text { selection of } \\
\text { assignment }\end{array}$ & $\begin{array}{c}\text { Sample } \\
\text { size } \\
(>\mathbf{1 0 0})\end{array}$ & $\begin{array}{c}\text { Follow } \\
\text { up rate } \\
>\text { 8o\% }\end{array}$ & $\begin{array}{c}\text { Comp } \\
\text { sociod } \\
\text { phic b } \\
\text { study }\end{array}$ \\
\hline $\begin{array}{l}\text { Bnat et al. } \\
(2018)\end{array}$ & 1 & 1 & 1 & 1 & 1 & 1 & 1 \\
$\begin{array}{l}\text { Mirsa et al. } \\
(2009)\end{array}$ & 1 & 1 & 1 & 1 & 1 & 1 & 1 \\
\end{tabular}


Ciptaningtyas et al./ Effect of Probiotics on the Frequency and Duration of Diarrhea

a. The effect of probiotics on reducing the frequency and duration of diarrhea in toddler 9 articles proved the effect of probiotics on the frequency and duration of diarrhea in toddlers

\begin{tabular}{|c|c|c|c|c|c|c|}
\hline $\begin{array}{c}\text { Author } \\
\text { (Year) }\end{array}$ & Country & $\begin{array}{l}\text { Study } \\
\text { Design }\end{array}$ & Sample & $\begin{array}{c}\mathbf{P} \\
\text { (Population) }\end{array}$ & $\begin{array}{c}\text { I } \\
\text { (Intervention) }\end{array}$ & (C \\
\hline $\begin{array}{l}\text { Bhat et } \\
\text { al., (2018) }\end{array}$ & India & RCT & $\begin{array}{l}\text { Oral and } \\
\text { zinc }=40 \\
\text { Probiotics }= \\
80\end{array}$ & $\begin{array}{l}6 \text { months }-5 \\
\text { years }\end{array}$ & $\begin{array}{l}\text { Assess the overall physical } \\
\text { examination, assessment }\end{array}$ & $\begin{array}{l}\text { Not asses } \\
\text { physical e } \\
\text { ment of vi } \\
\text { ment of hy } \\
\text { and sever }\end{array}$ \\
\hline $\begin{array}{l}\text { Rajagukg } \\
\text { uket al., } \\
\text { (2013) }\end{array}$ & Indonesia & RCT & $\begin{array}{l}\text { Probiotics }= \\
20 \\
\text { Synbiotics }= \\
20\end{array}$ & $\begin{array}{l}1 \text { year }-14 \\
\text { years }\end{array}$ & $\begin{array}{l}\text { Synbiotics (mixed) in children } \\
\text { with acute diarrhea. }\end{array}$ & $\begin{array}{l}\text { Did not se } \\
\text { duration : } \\
\text { diarrhea }\end{array}$ \\
\hline $\begin{array}{l}\text { Putra et } \\
\text { al., } \\
(2007) .\end{array}$ & Indonesia & RCT & $\begin{array}{l}\text { Probiotics }= \\
35 \\
\text { Placebo }= \\
35\end{array}$ & $\begin{array}{l}1 \text { month - } 12 \\
\text { months }\end{array}$ & $\begin{array}{l}\text { Compared the effects of pro- } \\
\text { biotic and placebo supplemen- } \\
\text { tation on the duration and fre- } \\
\text { quency of acute diarrhea in } \\
\text { infants. }\end{array}$ & $\begin{array}{l}\text { Did not see } \\
\text { biotic and p } \\
\text { mentation c } \\
\text { frequency. }\end{array}$ \\
\hline $\begin{array}{l}\text { Sharif et } \\
\text { al (2016) }\end{array}$ & Iran & RCT & $\begin{array}{l}\text { Probiotics }= \\
100 \\
\text { Placebo }= \\
100\end{array}$ & $\begin{array}{l}6 \text { months }-6 \\
\text { years }\end{array}$ & $\begin{array}{l}\text { Comparing the effects of } S \text {. } \\
\text { Boulardi and placebo adminis- } \\
\text { tration on the duration and } \\
\text { frequency of acute diarrhea in } \\
\text { infants. }\end{array}$ & $\begin{array}{l}\text { Did not se } \\
\text { boulardi a } \\
\text { probiotics }\end{array}$ \\
\hline $\begin{array}{l}\text { Sharif et } \\
\text { al (2017) }\end{array}$ & Iran & RCT & $\begin{array}{l}\text { Probiotics }= \\
60 \\
\text { Placebo }= \\
30\end{array}$ & $\begin{array}{l}1 \text { year }-5 \\
\text { years }\end{array}$ & $\begin{array}{l}\text { Comparing the effects of pro- } \\
\text { biotics and placebo on the } \\
\text { duration and frequency of } \\
\text { diarrhea }\end{array}$ & $\begin{array}{l}\text { Did not see } \\
\text { biotics and } \\
\text { duration an } \\
\text { diarrhea. }\end{array}$ \\
\hline
\end{tabular}


Ciptaningtyas et al./ Effect of Probiotics on the Frequency and Duration of Diarrhea

\begin{tabular}{|c|c|c|c|c|c|c|}
\hline $\begin{array}{l}\text { Schnadow } \\
\text { er et al., } \\
\text { (2018) }\end{array}$ & USA & RCT & $\begin{array}{l}\text { Probiotics = } \\
55 \\
\text { Placebo }= \\
60\end{array}$ & $\begin{array}{l}3 \text { months }-4 \\
\text { years }\end{array}$ & $\begin{array}{l}\text { Seeing the effectiveness of the } \\
\text { probiotic L. rhamnosus GG, } \\
\text { and placebo in children } \\
\text { suffering from acute gastro- } \\
\text { enteritis in children }\end{array}$ & $\begin{array}{l}\text { Did not see } \\
\text { of the probi } \\
\text { rhamnosus }\end{array}$ \\
\hline $\begin{array}{l}\text { Freedman } \\
\text { et al., } \\
\text { (2020) }\end{array}$ & Canada & $\mathrm{RCT}$ & $\begin{array}{l}\text { Probiotics }= \\
108 \\
\text { Placebo }= \\
102\end{array}$ & $\begin{array}{l}3 \text { months }-4 \\
\text { years }\end{array}$ & $\begin{array}{l}\text { Evaluating the effectiveness of } \\
\text { the probiotics of } L \text {. rhamnosus } \\
\text { and } L \text {. helveticus in children } \\
\text { aged } 3 \text { to } 48 \text { months in acute } \\
\text { gastroenteritis. }\end{array}$ & $\begin{array}{l}\text { Did not see } \\
\text { of the probi } \\
\text { rhamnosus }\end{array}$ \\
\hline
\end{tabular}

\section{b. Forest Plot}

\begin{tabular}{|c|c|c|c|c|c|c|c|c|c|}
\hline \multirow[b]{2}{*}{ Study or Subgroup } & \multicolumn{3}{|c|}{ Probiotics } & \multicolumn{3}{|c|}{ Non-probiotics } & \multicolumn{3}{|c|}{ Std. Mean Difference } \\
\hline & Mean & SD & Total & Mean & $\mathrm{SD}$ & Total & Weight & IV, Random, 95\% Cl & \\
\hline Bhat 2018 & 1.28 & 2.09 & 40 & 0.35 & 0.66 & 40 & $16.8 \%$ & $0.59[0.15,1.04]$ & \\
\hline Misra 2009 & 2.03 & 2 & 106 & 2.1 & 2 & 105 & $17.3 \%$ & $-0.03[-0.30,0.24]$ & \\
\hline Rajaguguk 2013 & 2 & 1.27 & 15 & 2 & 1.73 & 13 & $15.6 \%$ & $0.00[-0.74,0.74]$ & \\
\hline Sharif 2016 & 1.5 & 0.73 & 100 & 3.2 & 1.04 & 100 & $17.2 \%$ & $-1.88[-2.22,-1.55]$ & $\longrightarrow$ \\
\hline Sharif 2017 & 2.13 & 0.27 & 30 & 3.98 & 1.12 & 30 & $16.0 \%$ & $-2.24[-2.90,-1.59]$ & \\
\hline Sudha 2019 & 3.46 & 0.66 & 59 & 4.57 & 1.59 & 60 & $17.1 \%$ & $-0.90[-1.28,-0.53]$ & \\
\hline Total $(95 \% \mathrm{Cl})$ & & & 350 & & & 348 & $100.0 \%$ & $-0.74[-1.60,0.12]$ & \\
\hline $\begin{array}{l}\text { Heterogeneity: } \mathrm{Tau}^{2}= \\
\text { Test for overall effect }\end{array}$ & $\begin{array}{l}1.09 ; \mathrm{Ch} \\
\mathrm{Z}=1.70\end{array}$ & $\begin{array}{l}i^{2}=12 \\
(P=0\end{array}$ & $\begin{array}{l}29.36, \mathrm{c} \\
.09)\end{array}$ & $f=5($ & .000 & 1); $l^{2}$ & $=96 \%$ & & -2 \\
\hline
\end{tabular}




\section{c. Funnel Plot}

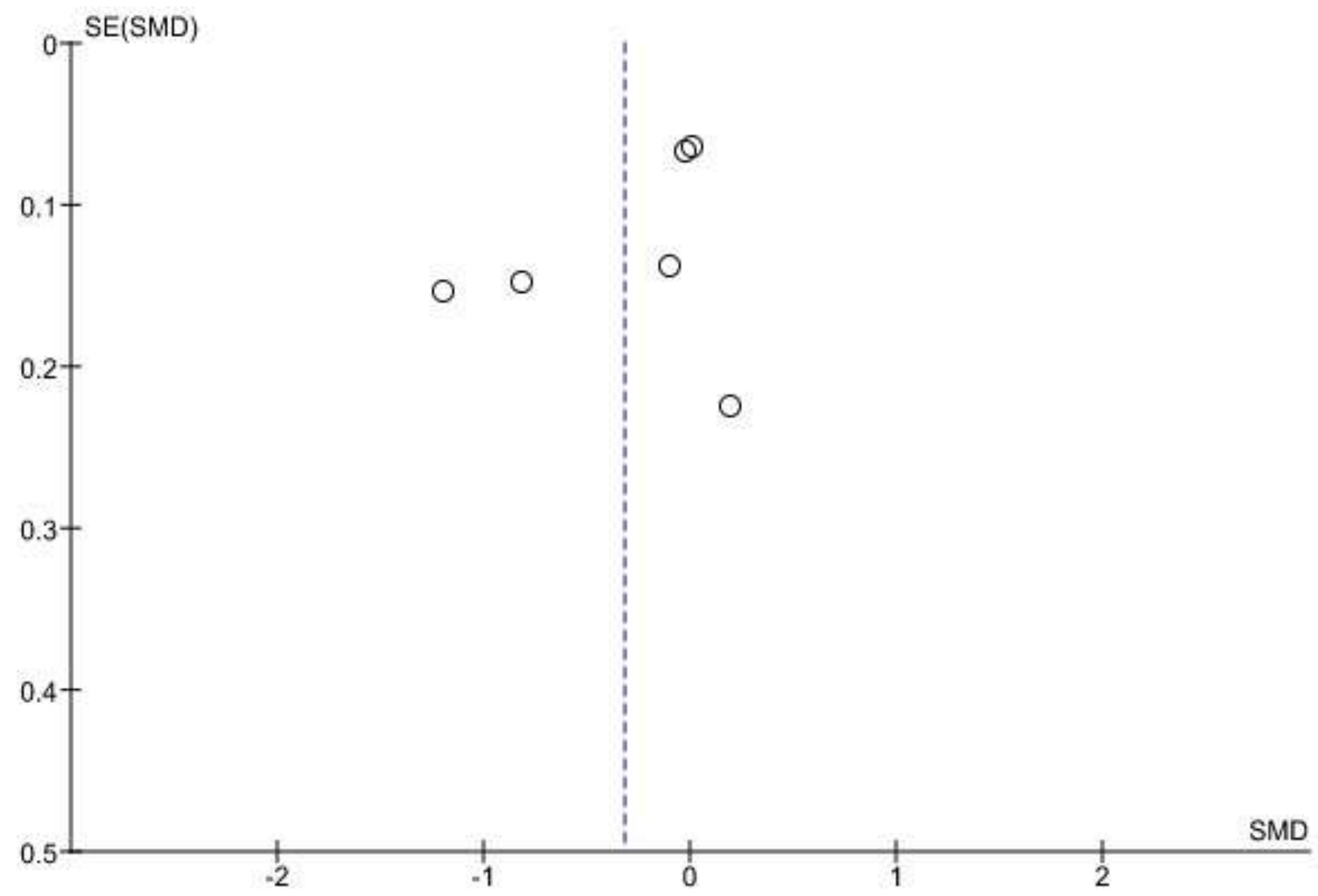

\section{Figure 3. Funnel plot of the effect of probiotics on frequency of diarrhea in children under five}

Based on the results of the forest plot (Figure 2) 4, it was shown that probiotics decreased the duration of childhood diarrhea by -0.32 times higher compared to placebo and it was not statistically significant $(\mathrm{p}=0.07)$. The heterogeneity of the research data shows $\mathrm{I}^{2}=94 \%$ so that the distribution of the data is heterogeneous (random effect model).

The funnel plot shows a publication bias which is indicated by asymmetry of the right and left plots where 4 plots are on the right and 2 plots are on the left. The plot on the left of the graph has a standard error between 0.1 and 0.2 and the plot on the right has a standard error between 0.1 and o.3. Bias also occurs from an imbalance between the distance between studies on both the right and left of the funnel plot. And do not form an inverted funnel triangle. Based on the results of the forest plot (Figure 3) 4, it was shown that probiotics decreased -0.32 times the duration of childhood diarrhea compared to placebo and it was not statistically significant $(p=0.07)$. The heterogeneity of the research data shows I $2=94 \%$ so that the distribution of the data is stated to be heterogeneous (random effect model).

The funnel plot shows a publication bias which is indicated by asymmetry of the right and left plots where 4 plots are on the right and 2 plots are on the left. The plot on the left of the graph has a standard error between 0.1 and 0.2 and the plot on the right has a standard error between 0.1 and 0.3 . Bias also occurs from an imbalance between 
Ciptaningtyas et al./ Effect of Probiotics on the Frequency and Duration of Diarrhea

the distance between studies on both the form an inverted funnel triangle.

right and left of the funnel plot. And do not

\section{d. Forest Plot}

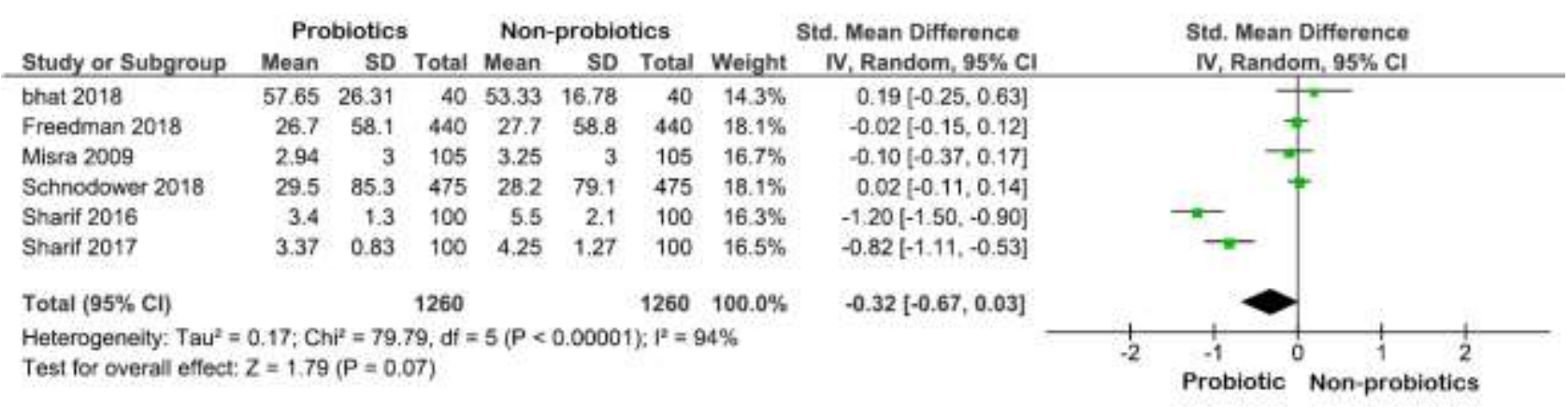

\section{Figure 4. Forest plot effect of probiotics on duration of diarrhea in children under five}

\section{e. Funnel Plot}

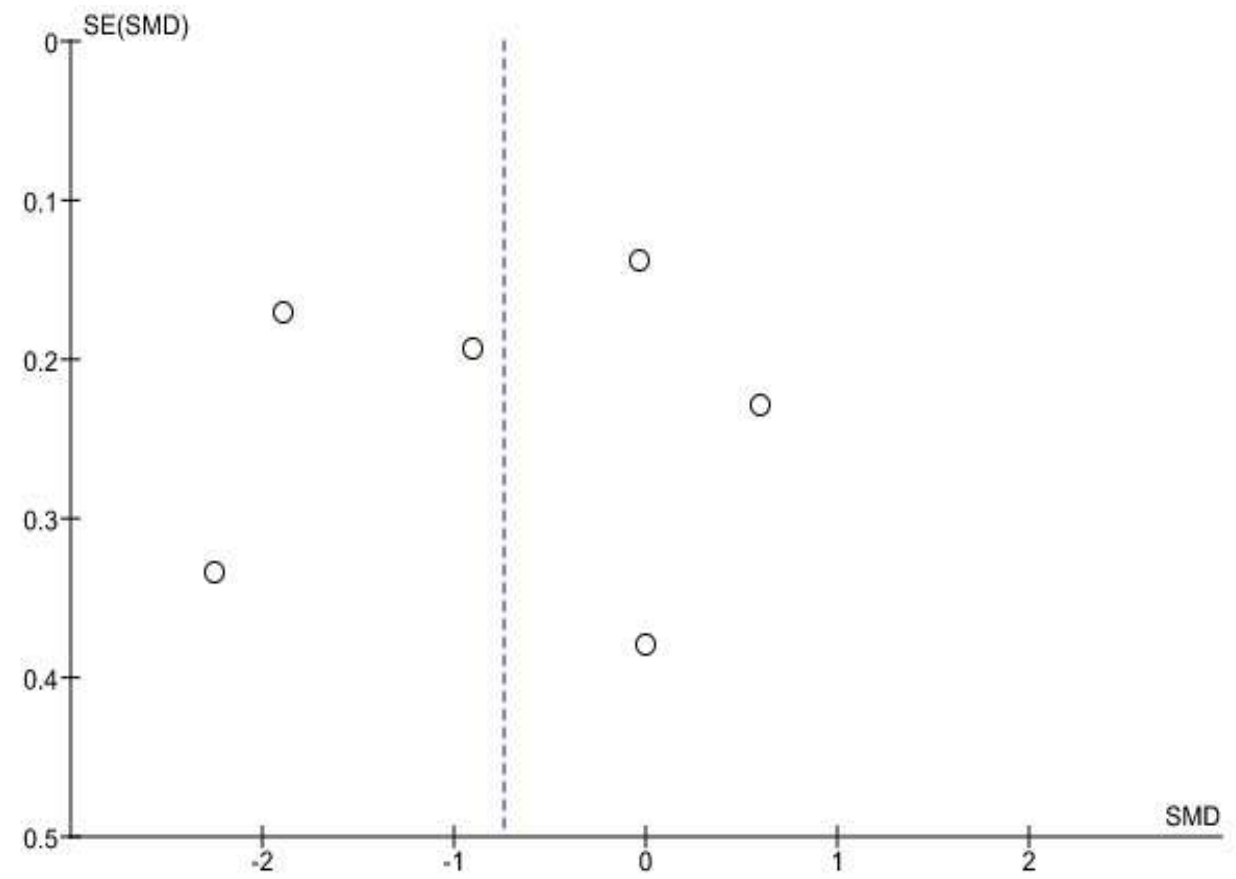

Figure 5. Funnel plot of the effect of probiotics on duration of diarrhea in children under five

\section{DISCUSSION}

This systematic study and meta-analysis research raised the theme of the effect of probiotics on the frequency and duration of diarrhea in toddlers. This study discussed data about probiotics that were considered to have a positive effect on the frequency and duration of diarrhea in toddlers. The number of relevant research published and accessible was still small and also has data access problems (data duplication) (Murti, 2018).

Confounding factors affected the relationship or effect of exposure to the occurrence of the disease estimated (estimated) by the study was not the same as the relationship or effect that actually 
occurred in the target population, it lead to invalid study results (Murti, 2018).

The combined estimates were processed using RevMan 5.3 with the Continous method. This method was used to analyze the effect size or standardized mean difference in the bivariate data of two groups that had been controlled for confounding factors by randomization. The results of the systematic study and metaanalysis were presented in the form of a forest plot and a funnel plot. The forest plot provided an overview of information from each of the studies examined in the metaanalysis, and estimates of the overall results (Murti, 2018).

The results of the systematic study and meta-analysis were presented in the form of a forest plot and a funnel plot. Forest plots provided an overview of information from each of the studies examined in the meta-analysis, and estimates of the overall results (Murti, 2018). The forest plot showed the amount of variation (heterogeneity) between study results visually (Akobeng in Murti, 2018).

A funnel plot is a diagram in a metaanalysis used to demonstrate possible publication bias. The funnel plot shows the relationship between the effect size of the study and the sample size or standard error of the effect size of the various studies (Murti, 2018).

Systematic review and meta-analysis in this study were carried out with the aim of increasing the generalizability of the findings and obtaining convincing conclusions from various similar studies regarding the effects of probiotics on the frequency and duration of diarrhea in toddlers.

This study is in line with the study that was conducted for 15 months involving 120 toddlers aged 6 months - 5 years who were randomly selected and divided into 3 groups. Group 1 received oral rehydration therapy and zinc. 2nd group with Bacillus clausii. Group 3 with Saccharomyces boulardii.

This study was supported by a study done by Rajagukguk et al., (2013) which was carried out for 3 months involving 40 children aged 1-14 years, with a sample of more men (52\%) than women (48\%) and divided into probiotic groups and the synbiotic group. The probiotic group received probiotics.

\section{AUTHOR CONTRIBUTION}

Wahyu Agustin is the main researcher who selected topics, explored and collected research data. Bhisma Murti, Setyo Sri Raharjo, played a role in analyzing data and reviewing research documents.

\section{CONFLICT OF INTEREST}

There was no conflict of interest.

\section{FUNDING AND SPONSORSHIP}

This study used personal funds from the main researcher.

\section{ACKNOWLEDGEMENT}

We are very grateful to database providers of PubMed, Springer Link, Cochrane Database, Hindawi, Elsevier, JBBA, LWW, Google Scholar.

\section{REFERENCE}

Hatta M, Supriatmo AM, Sinuhaji AB, Hasibuan B, Nasution FL (2011). Comparison of zinc-probiotic combination therapy to zinc therapy alone in reducing the severity of acute diarrhea. $\mathrm{J}$ Dent, 51(1): 1-6.

Htwe K, Yee KS, Tin M, Vandenplas Y. (2008). Effect of Saccharomyces boulardii in the treatment of acute watery diarrhea in Myanmar children: a randomized controlled study. Am J Trop Med Hyg, 78 (1): 214-216. 
Lolopayung M, Mukaddas A, Faustine I (2013). Evaluasi penggunaan kombinasi zink dan probiotik pada penanganan pasien diare anak di instalasi rawat inap RSUD UndataPalutahun (Evaluation of the use of a combination of zinc and probiotics in the management of pediatric diarrhea patients in the inpatient installation of the Undata Hospital, Palu). J Sci Technol, 1(1): 1-8.

Murti B (2018). Prinsip dan metode riset epidemiologi (5th ed). Surakarta: Program Studi Ilmu Kesehatan Masyarakat.

Pandey KR, Naik SR, Vakil BV (2015). Probiotics, prebiotics and synbiotics-a review. Int J Food Sci Technol, 52(12): 7577-7587.

Rajagukguk S, Manoppo C, Mantik M (2013). Pengaruh pemberian probiotik dan sinbiotik pada anak dengan diare akut di RSUP Prof. Dr. R.D Kandou Manado (The effect of probiotics and synbiotics in children with acute diarrhea in Prof. Dr. R.D Kandou Manado). Jurnal e-Biomedik (eBM). 1(1): 587-591.

Sudha MR, Jayanthi N, Pandey DC, Verma AK (2019). Bacillus clausii UBBC-07 reduces severity of diarrhoea in children under 5 years of age: a double blind placebo controlled study. Benef Microbes, 10(2): 149-154.

Waspada IMI (2012). Suplementasi probiotik pada terapi standar zinc dan cairan rehidrasi oral pada anak usia 6-36 bulan dengan diare akut (Probiotic supplementation with standard zinc therapy and oral rehydration fluids in children aged 6-36 months with acute diarrhea). Tesis. Jakarta. Universitas Indonesia.

WGO (2008). Probiotics and Prebiotics. World Gastroenterology Organisation. https://www.worldgastroenterology.o $\mathrm{rg} /$ guidelines/globalguidelines/probi otics-and-prebiotics. 